\title{
Antifungal Activity of Some Lactic Acid Bacteria Against Several Soil- borne Fungal Pathogens Isolated from Strawberry Plants
}

\author{
Elif Canpolat $^{1}$, Müzeyyen Müge Doğaner ${ }^{1}$, Sibel Derviş ${ }^{2}$, Çiğdem Ulubaş Serçe ${ }^{1^{*}}$
}

${ }^{1}$ Department of Plant Production and Technologies, Ayhan Şahenk Faculty of Agricultural Sciences and Technologies, Nigde Ömer Halisdemir University, 51240 Niğde, Turkey

${ }^{2}$ Department of Plant and Animal Production, Vocational School of Kizlltepe, Mardin Artuklu University, 47200 Mardin, Turkey AR T I C LE INFO

Research Article

Received 16 April 2018

Accepted 14 August 2018

Keywords:

Lactic acid bacteria

Bacteriocin like substance

Biological management

Soil-borne pathogens

Strawberry

*Corresponding Author:

E-mail: cigdemserce@ohu.edu.tr \begin{abstract}
A B S T R A C T
Developing as an alternative plant disease control method by using beneficial microorganisms and their metabolites has gained so much importance in recent years. In this study, the possibilities of using microorganisms which have potential antimicrobial effects on controlling soil-borne fungi at strawberry production were investigated. Effects of different lactic acid bacteria (LAB) strains on the development of several soil-borne fungi were studied in vitro and in vivo. LAB were screened for antifungal activity by using cell free supernatant against Fusarium sp., Rhizoctonia sp., Macrophomina sp., Botrytis sp., Phtopythium sp., Cylindrocarpon sp. and Pestalotiopsis sp. Cell free supernatant of LAB isolates showed promising antifungal activity. In vitro effective strains of LAB were tested in pot experiments to search their effects on disease development and plant growth. While the antifungal effects of all LAB strains tested in vitro experiments exhibited promising results, in vivo experiments revealed similar effects on different fungi genera.
\end{abstract}

DOI: https://doi.org/10.24925/turjaf.v6i9.1163-1167.1975

\section{Introduction}

The incidence and severity of soil-borne diseases in strawberry (Fragaria $X$ ananassa) cultivation appear to be increasing every year and the crop loss due to these diseases become a major problem in the strawberry production. Wilting, root rot, yellowing, stunting, dieback and eventual death are common symptoms caused by soil borne fungal pathogens. Among the fungi associated with strawberry roots, Rhizoctonia spp., Fusarium spp., Macrophomina spp., Pythium spp., Pytophthora spp. and Cylindrocarpon spp. are widely distributed worldwide while Coniothyrium spp., Hainessia spp. and Alternaria spp. are less frequently encountered (Maas, 1998). Most of these fungi are common soil inhabitants and their management is very difficult due to many factors such as the special features of life cycles of the pathogen the diversity of the microbial populations, the host characteristics, and the physical and chemical properties of the soil. There are several disadvantages in the management of such pathogens, particularly in chemical control, such as the adverse effects of pesticide residues on humans and other living things, and the emergence of pesticide resistance in pathogen populations. For this reason, studies on the use of biological control agents against plant pathogens have gained more importance for being an alternative to the pesticides. By biological management, the plant diseases can often be controlled with reduced or without adverse effect on the environment. There are beneficial microorganisms in soil that may increase the resistance of the plant to diseases by forming a defense line against the pathogens in the root region of the plant (Aksoy, 2006; Benlioğlu, 2012). Pseudomonas fluorescens, Agrobacterium radiobacter, Bacillus subtilis, B. cereus, B. amyloliquefaciens, Trichoderma virens, Burkholderia cepacia, Saccharomyces sp., Gliocladium sp. and Streptomyces sp. have been demonstrated in previous studies to be used as antimicrobial agents against several phytopathogenic fungi (Vestberg et al., 2004).

In recent years, lactic acid bacteria (LAB) have attracted much attention as antimicrobial agents. There are various researches on LAB applications in traditional food and feed fermentation and preservation (Kim, 1993; Johan and Jesper, 2005). LAB together with hydrogen peroxide and carbon dioxide, produce a number of antimicrobial compounds and active substances such as lactic acid, propionic acid, antibiotic and bacteriocin (Ouwehand, 1998). The produced "bacteriocin" molecule in the peptide structure inhibits the deterioration in food 
and the development of bacteria causing foodborne infections, and thus acts as a potential biological protective agent to prolong the shelf life of food (Dykes et al., 1994).

Even the presence of the evidence about LAB antimicrobial effect on plant pathogens, there is not much research has been performed on their potential on soilborne disease management. Because of that, this study was performed to determine the effects of LAB against fungal pathogens in vitro and in vivo in the management of soil-borne fungal diseases causing problems in strawberry cultivation.

\section{Material and Methods}

\section{Material}

The strawberry plant materials (Fragaria $\times$ ananasa cv Festival) were kindly provided from YALTIR Agricultural Products Inc. (Adana, Turkey). Lactic acid bacteria $(\mathrm{LAB})$ were isolated from various regional cheeses from Niğde province. The isolated Pediococcus pentosaceus SE1, Pediococcus acidilactici EF1, Enterococcus faecium EC1 and Lactobacillus sp. LAB strains were used. Fungal species have been isolated from the root and crown of strawberries, which indicate disease symptoms and collected in 2014 from strawberry cultivation areas in the Mediterranean Region. Five isolates from each Fusarium spp., Rhizoctonia spp, Macrophomina spp. and Pestalotiopsis spp., four isolates from Cylindrocarpon spp., two isolates from Botrytis cinerea and one isolate Pythium sp. were used as phytopathogenic soil-borne fungi.

\section{Methods}

Pathogenicity test of fungi on strawberry plants: Pathogenicity test were performed according to Turhan and Turhan (1989). Strawberry plants were planted into 1:2 peat:sand and 1:19 fungi culture (six week fungi culture on $135 \mathrm{gr}$ sand, $15 \mathrm{gr}$ corn flour and $20 \mathrm{ml}$ potato juice (200 gr potato / $1 \mathrm{~L}$ distilled water). Before planting, the root zone of the strawberry plants was shaved, and the crown was punctured with needles.

Following inoculation, the plants were irrigated regularly. After 6 weeks of the inoculation, the plants were removed, and the root parts of each plant evaluated for presence of disease symptoms. Root symptoms of each plant were assessed according to scale 0-5 (Alaniz et al., 2007). Re-isolation of the pathogens from the browning roots was carried out by culturing on PDA medium.

Investigation of in vitro antifungal activities of lactic acid bacteria: Two different well-diffusion methods were applied to test the role of LAB against fungal growth. In the first method, mycelia of fungus with a diameter of $6 \mathrm{~mm}$ was picked from the five days old fungal culture and placed on the center of PDA plate. In respect to welldiffusion method $10^{6} \mathrm{CFU} / \mathrm{ml}$ bacterial suspensions were added into the wells with a diameter of $6 \mathrm{~mm}$ which were placed $3 \mathrm{~cm}$ away from the fungal mycelia. Sterile water was used as control for each application. Plates then were incubated at $27^{\circ} \mathrm{C}$.
In the second method, similar procedure to the first method was applied during fungal inoculation of the test plates. In respect to well-diffusion method cell free supernatant (CFSs) were added into the wells with a diameter of $6 \mathrm{~mm}$ which were placed $3 \mathrm{~cm}$ away from the fungal mycelia. Sterile water was used as control for each application. Plates then were incubated at $27^{\circ} \mathrm{C}$.

The distance between mycelial growth and CFSs was measured in all petri dishes during 20 days. Positive response is the formation of visible inhibition zones around the fungal colonies. CFS was isolated according to Bhunia et al. (1988). The antifungal effect was evaluated by measuring the diameters of the zones formed around the well.

Investigation of in vivo antifungal activities of lactic acid bacteria: Pots with a volume of one liter were filled with a ratio of $1: 2$ peat and sand mixture, respectively. To get CFSs, LAB strains were cultured in $1 \mathrm{~L}$ flasks in liquid MRS media at $37^{\circ} \mathrm{C}$ for 18 hours. The bacterial cells were removed by centrifugation and the remained suspension was used. Strawberry plants were plunged into this solution of LAB and planted to the pots. Later, as the pathogenic inoculum, solutions prepared by disruption of fungal mycelia developed in the liquid PDA medium and adjusted to a density of $5 \times 10^{5}$ spores / $\mathrm{ml}$ were given in equal amounts. Control pots were designed as plant + fungus, plant + LAB strain and plant only. The potting trials were carried out in triplicate and each application was established with 10 plants and the whole experiment was repeated twice. Two months after the establishment of the experiment, the plants were evaluated according to scale 0-5 (0: healthy, without lesion; 1: 0-10\% root decrease, slight color change; 2 : 10-20\% root decrease, slight color change; 3: $25-50 \%$ root decrease, medium color change; $4:>50 \%$ root decrease, strong color change; 5: killed plant).

\section{Statistical Evaluations}

Inhibition zone as a result of in vitro experiments and scale values as a result of in vivo experiments were obtained for control and pathogens 3 replicates. These values were subjected to analysis of variance (ANOVA). When statistical differences were found as a result of analysis of variance, mean comparisons were made with LSD method for pathogens; Groups resulting from mean comparisons were presented with the original (untransformed) data. SAS and SPSS software's were used for statistical analysis.

\section{Results and Discussion}

\section{Pathogenicity}

Strawberry plants were removed from soil and roots of the plants were examined. While there was no symptom in the control strawberry plants, rapid peeling of the roots by darkening was observed in the roots of the strawberry plants inoculated with fungi (Figure 1). Rhizoctonia sp., Macrophomina sp., Botrytis sp., Phtopythium sp., Cylindrocarpon sp., Pestalotiopsis sp. isolates caused lesions in the root and crown parts of the strawberry plants. As a result of re-isolation from root parts of the inoculated plants, pathogen isolates were recovered. 

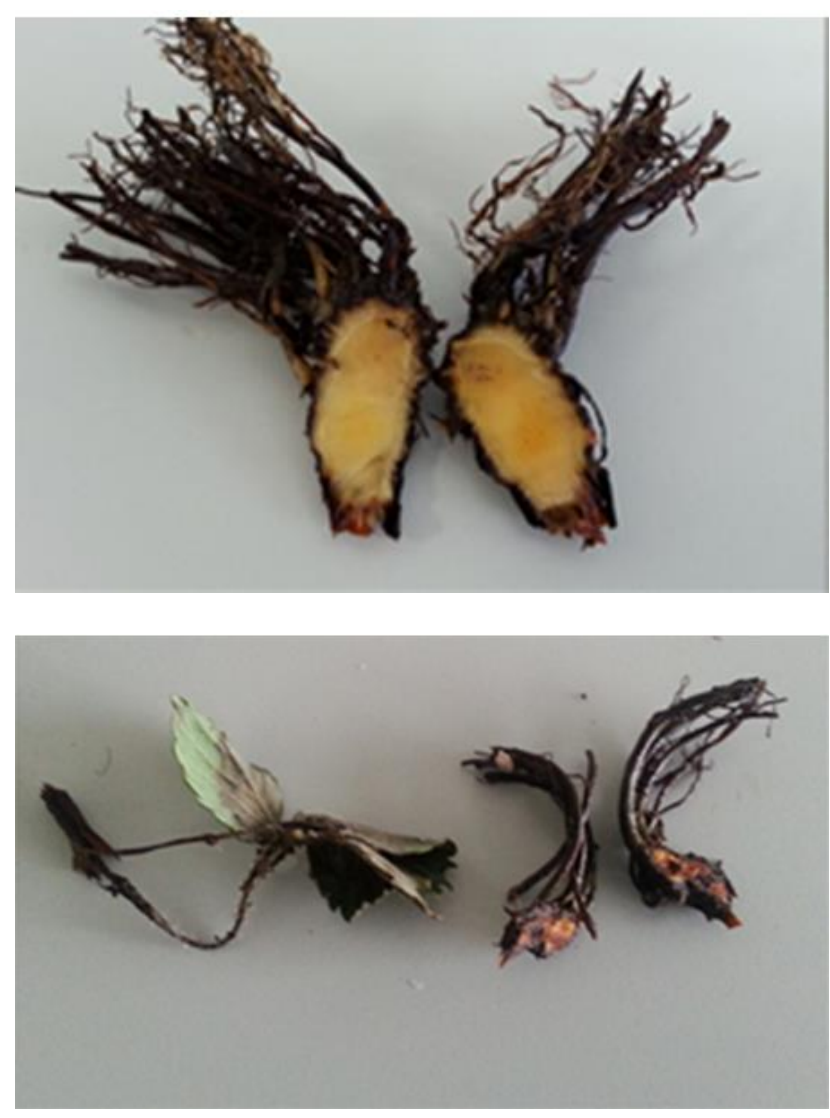

Figure1 Root and crown development of control and fungi inoculated strawberry plants
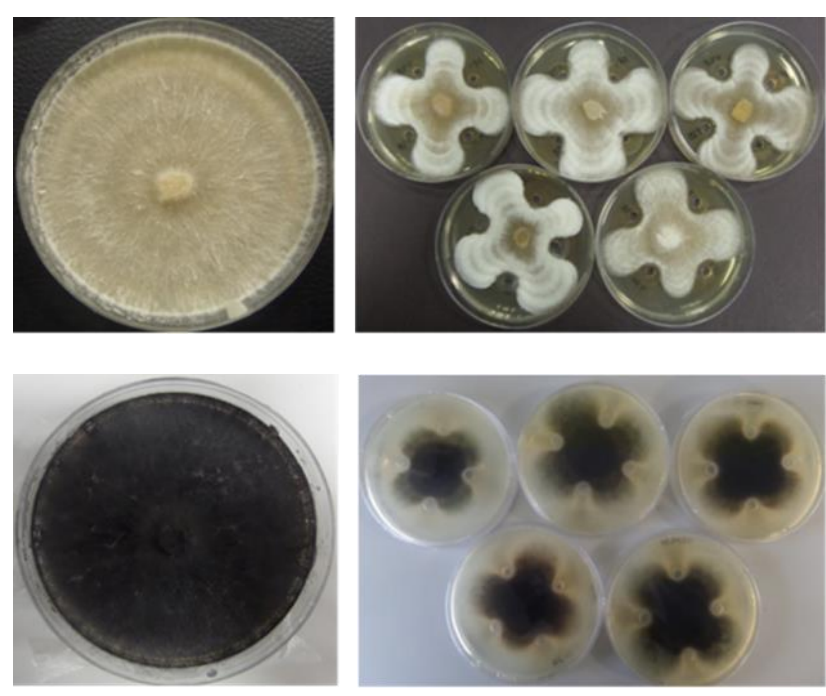

Figure 2 CFSs of Lactic acid bacteria antifungal effects to Rhizoctonia sp. and Macrophomina sp. isolates

\section{In Vitro Antifungal Activity of Lactic Acid Bacteria}

Antifungal activity studies have been conducted with two in vitro methods. In the first method, no inhibition in mycelial growth was observed in any of the fungal and bacterial combination. This result is probably due to special temperature and medium requirements of each bacteria and fungus isolates used in the study. After 5-7 days of the experiment, mycelial colonies covered 70-
$100 \%$ of the surface of media by varying according to the fungus species; however the inhibition zone formations were not clear.

The second well diffusion method with CFS, yielded promising results. The antifungal effect of lactic acid bacterial isolates on Fusarium sp., Rhizoctonia sp., Macrophomina sp., Botrytis sp., Phtopythium sp., Cylindrocarpon sp. and Pestalotiopsis sp. were obtained. Inhibition zone were observed in all isolates of each fungus species tested (Figure 2). All bacteria tested in the study showed antimicrobial effects in varying degrees against all fungi.

Four LAB bacteria showed similar level of antimicrobial activity in every fungal genus tested. The highest effect of LAB bacteria was observed on Pythium and Macrophomina isolates. In these fungi, the zones formed by CFS effect are at the highest values, so the inhibition of mycelial growth is the highest (Figure 3). The smallest inhibition zone was obtained from Cylindrocarpon, followed by Botrytis genus.

The results of statistical comparison of the antifungal activity of LAB against fungus isolates by well diffusion method with CFSs showed that, the highest inhibition of mycelial growth occurred in Pythium species for each CFSs. The effects of CFSs of other LAB species were same on Pythium and Macrophomina, except Lactobacillus (Table 1). Macrophomina and Pestalotiopsis genera were not statistically different in the effect of CFS. The CFS effects of species other than Enterococcus faecium were the same in Rhizoctonia and Fusarium. It has been determined that all of the CFS tested had similar level of antifungal effect on Botrytis and Cylindrocarpon genera.

In vivo Antifungal Activity of Lactic Acid Bacteria

Some of the strawberry plants inoculated with fungi being received $\mathrm{LABs}$ treatment were observed to have died within 2 months but some of them remained alive. CFS treated plants protected their vitality; symptoms were observed in the roots and evaluated according to the scale.

Depending on the LAB species, the scale values in the plants inoculated with Rhizoctonia, Macrophomina, Botrytis and Pythium were not only higher but also lower than the control plants (Figure 4).

In the case of Cylindrocarpon species, disease scale values from almost all CFSs treatments, (except for CFS of Enterococcus) were lower than those of fungus control plants. In the same fungus, there were significant differences in disease scale among LAB bacteria. According to the graph, the scale value for $P$. pentosaceus is low in Pythium sp. Likewise, CFSs of Enterococcus and Lactobacillus reduced the severity of Phtopythium infections. However, comparisons of t-test (LSD) results of the obtained $0-5$ scale mean values from pot experiments, it was determined that there was no difference between the antifungal effects of CFSs against fungus infections.

Despite the promising results on the study of investigating in vitro effect of four different CFSs on different soil borne fungal pathogens, there was no difference between the effects of LABs on infections of fungi species in vivo studies. 


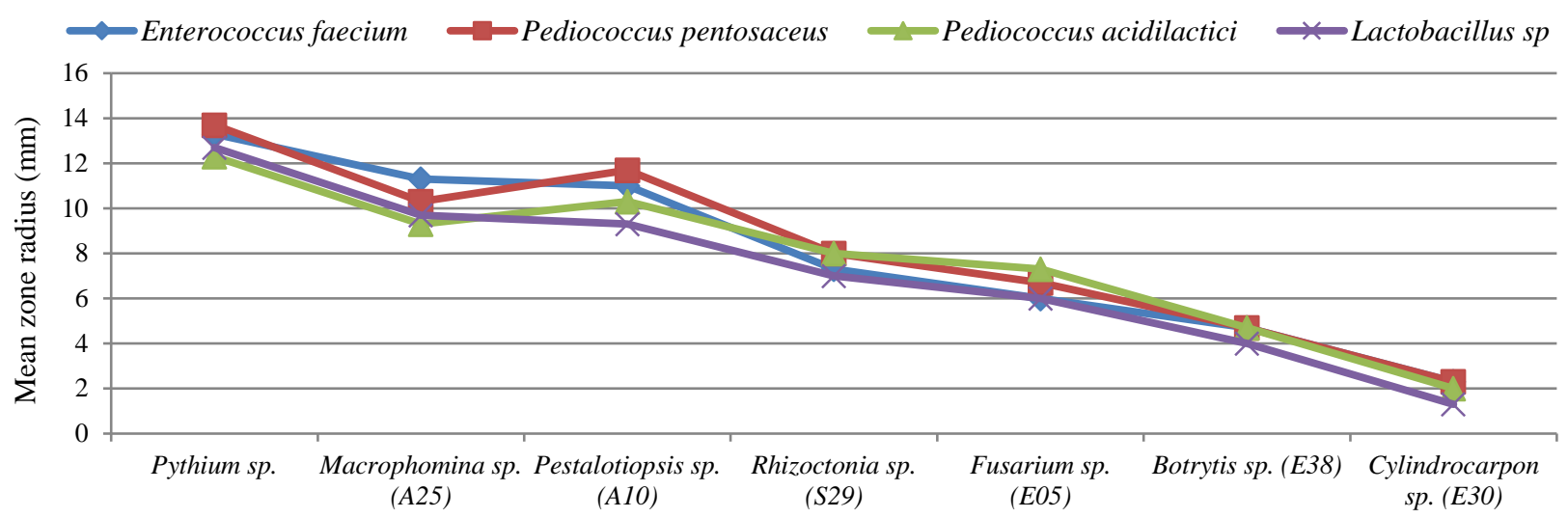

Figure 3 The in vitro effects of lactic acid bacterial supernatant on fungus genera

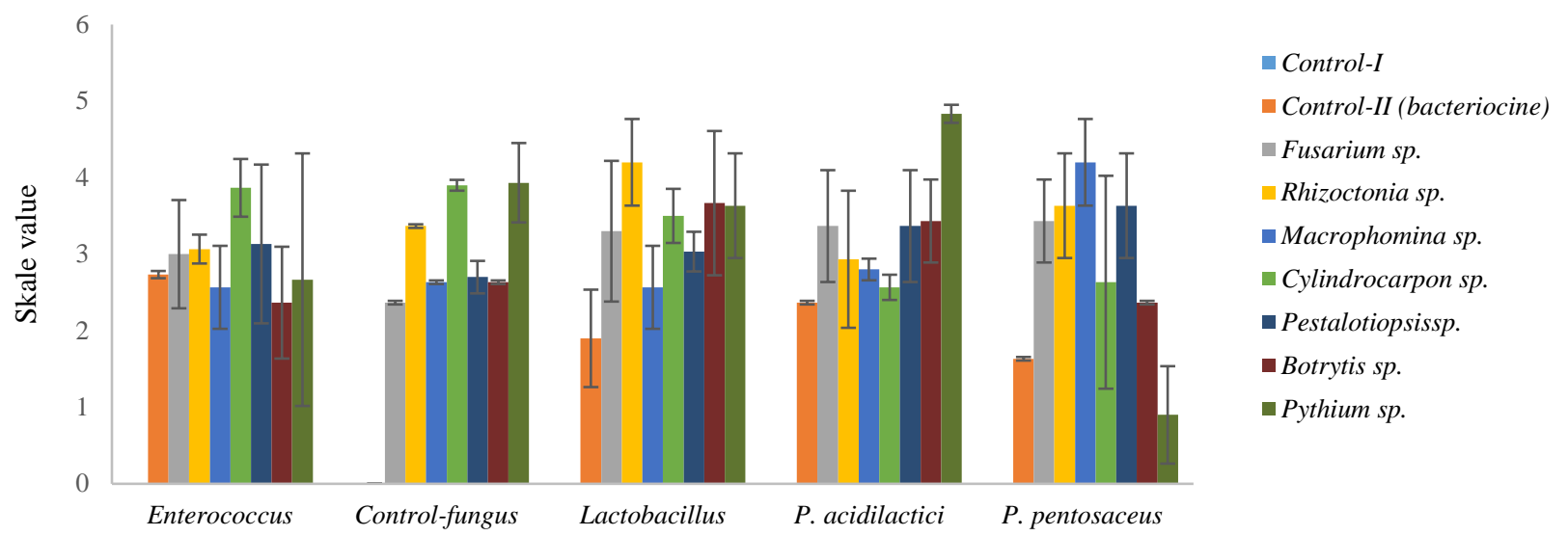

Figure 4 Graphical comparison of the t-test (LSD) variance analysis results $(\mathrm{P}<0.0001)$ of $0-5$ scale values of effects of lactic acid bacterial supernatant against fungus isolates in in vivo potting experiments

Table 1 Statistical comparison of efficacy of lactic acid bacterial against fungus isolates by well diffusion method according to inhibition zone

\begin{tabular}{l|cccc}
\hline \multirow{2}{*}{\multicolumn{1}{c|}{ Fungus $^{\mathrm{a}}$}} & \multicolumn{4}{c}{ Mean inhibition zone (mm) } \\
\cline { 2 - 5 } & $\begin{array}{c}\text { Enterococcus } \\
\text { faecium } \text { (EC1) }\end{array}$ & $\begin{array}{c}\text { Pediococcus } \\
\text { pentosaceus } \text { (SE1) }\end{array}$ & $\begin{array}{c}\text { Pediococcus } \\
\text { acidilactici (EF1) }\end{array}$ & $\begin{array}{c}\text { Lactobacillus } \\
\text { sp. }\end{array}$ \\
\hline Pythium sp. & $13.3^{\mathrm{ab}}$ & $13.7^{\mathrm{a}}$ & $12.3^{\mathrm{a}}$ & $12.7^{\mathrm{a}}$ \\
Macrophomina sp. (A25) & $11.3^{\mathrm{ab}}$ & $10.3^{\mathrm{ab}}$ & $09.3^{\mathrm{ab}}$ & $09.7^{\mathrm{b}}$ \\
Pestalotiopsis sp. (A10) & $11.0^{\mathrm{ab}}$ & $11.7^{\mathrm{b}}$ & $10.3^{\mathrm{bc}}$ & $09.3^{\mathrm{b}}$ \\
Rhizoctonia sp. (S29) & $07.3^{\mathrm{c}}$ & $08.0^{\mathrm{c}}$ & $08.0^{\mathrm{bc}}$ & $07.0^{\mathrm{c}}$ \\
Fusarium sp. (E05) & $06.0^{\mathrm{de}}$ & $06.7^{\mathrm{cd}}$ & $07.3 \mathrm{c}$ & $06.0^{\mathrm{cd}}$ \\
Botrytis sp. (E38) & $04.7^{\mathrm{e}}$ & $04.7^{\mathrm{de}}$ & $04.7^{\mathrm{de}}$ & $04.0^{\mathrm{de}}$ \\
Cylindrocarpon sp. (E30) & $02.3^{\mathrm{e}}$ & $02.3^{\mathrm{e}}$ & $02.0^{\mathrm{e}}$ & $01.3^{\mathrm{e}}$ \\
\hline
\end{tabular}

\footnotetext{
${ }^{a}$ The isolates used in vivo experiments were given in brackets. ${ }^{\mathrm{b}}$ There is no difference between the averages indicated by the same letter according to ANOVA test $(\mathrm{P}<0.0001)$.
}

Temperature changes, the amount of moisture in the environment and the variety of competitive microorganisms may have effect on the results. It is also deduced that moisture, air, flora, organic and inorganic compounds of soil greatly affect the inhibition of CFSs in in vivo experiments. Apart from that, it is also useful to evaluate the CFS application pattern and frequency in further research.

In a study with five different Lactobacillus strains including Lactobacillus acidophilus and Lactobacillus plantarum NRRL B-4524 indicated that bacterial strains showed low, medium and high in vivo inhibition effects against Fusarium oxysporum isolated from tomato,
Fusarium oxysporum and Rhizoctonia solani isolated from cotton and Sclerotium rolfsii isolated from onion, respectively (Hamed et al., 2011). Results of another study, where development of cucumber plant in presence of LAB and biological control of Pythium ultimum-which causes root rot-were investigated, demonstrated that LAB did not have a significant effect on development of healthy plants in vivo, however same plants lost their fresh weight up to $85 \%$ against Pythium ultimum in absence of LAB as plants infected with Pythium ultimum protected their fresh weight up to $65 \%$ in presence of LAB (Lutz et al., 2012). In another study, where in vitro biological control of Colletotrichium capsici- which 
causes anthracnose in pepper plant-was investigated, while seeds infected with $C$. capsici had a $25,25 \%$ of germination capability other seeds treated with Lactobacillus parasasei and Lactobacillus plantarum strains and their supernatants had germination capability between a range of $84,75 \%$ and $96 \%$ (El-Mabrok et al., 2012). In another study with four LAB (Lactococcus lactis subsp. lactis, Lactococcus lactis subsp. lactis biovar. diacetylactis, Leuconostoc mesenteroides subsp. mesenteroides and Leuconostoc mesenteroides subsp. mesenteroides biovar. dextranicum) showed good antifungal activity against Fusarium oxysporum f. sp. albedinis. It was observed that both bacterial culture and supernatant of strains could be used as growth inhibitor against this fungus. It was also stated that further studies are required to determine the potential of $\mathrm{LAB}$ as a biocontrol agent against Fusarium (Zebboudj et al., 2014). In another study to evaluate the effectiveness of selected LAB strains against Fusarium species isolated from different parts of infected pepper plants and leaves of rose showed strong antifungal effect against Fusarium sp. (Husain et al., 2017).

Several bacterial and fungal plant diseases have been reported in the past 50 years where different microorganisms have been used as biocontrol agents. There is little information about the relationship of LAB to phytopathogenic fungi. Limited in vitro studies have been reported on the efficacy of LAB against phytopathogenic fungi. As a result of the investigations, it is concluded that LAB may be a new biological control agent against soil-borne phytopathogens. LAB can produce many different antifungal substances in vitro, but its antifungal activity mechanism in vivo condition is not clear due to the synergistic interaction of different compounds with different soil microorganisms. Despite potentially toxic effects on wildlife and the environment, producers use chemical fungicides to control plant diseases caused by fungal pathogens. The development of new phytopathogens resistant to fungicides is an important problem related to this situation. In this regard, efforts should be continued to investigate and put new biocontrol agents into action. LAB has been used for years in the preservation of food and dairy products and is considered safe for food. For this reason, metabolic products of LAB can be used safely under the control of plant pathogenic fungi.

\section{Acknowledgement}

This scientific study was fully supported by a Project of FEB 2015/13 BAGEP, Scientific Research Projects section of Niğde Ömer Halisdemir University. The authors also thank to Prof. Dr. Sedat Serçe due to his assistance on providing strawberry plant samples and statistical analysis.

\section{References}

Aksoy HM. 2006. Biological control of soil-borne fungal pathogens by fluorescent Pseudomonads. J. Agricultural Faculty of OMU, 21(3): 364-369.
Alaniz S, Leon M, García-Jiménez J, Aba-Campos P, Armengol J. 2007. Characterization of Cylindrocarpon species associated with black-foot disease of grapevine in Spain. Plant Disease, 91: 1187-1193. DOI:10.1094/ PDIS-91-91187.

Benlioğlu K. 2012. Plant Pathogenic Bacteria, Plant Protection Lecture notes.

Bhunia AK, Johnson MC, Ray B. 1988. Purification, characterization and antimicrobial spectrum of a bacteriocin produced by Pediococcus acidilactici. Journal of Applied Bacteriology, 65: 261-268. https://doi.org/10.1111/j.13652672.1988.tb01893.x

Dykes GA, Cloete TE, Holy A. 1994. Identification of Leuconostoc species associated with the spoilage of vacuum-packaged Vienna sausage by DNA-DNA hybridization. International Journal of Food Microbiology, 11: 271-274. DOI10.1006/fmic.1994.1030

El-Mabrok ASW, Hassan Z, Mokhtar AH, Hussain KMA, Kahar FKSBA. 2012. Screening of Lactic acid bacteria as biocontrol against (Colletotrichum capsici) on chilli bangi. Research Journal of Applied Sciences, 7 (9-12): 466-473. DOI: 10.3923/rjasci.2012.466.473.

Hamed HA, Moustafa YA, Abdel-Aziz SM. 2011. In vivo efficacy of Lactic Acid Bacteria in biological control against Fusarium oxysporum for protection of tomato plant. Life Science Journal, 8 (4): 462-468.

Husain A. Hassan Z. Huda-Faujan N, Lani MN. 2017. Antifungal activity of Lactic Acid Bacteria isolated from soil rhizosphere on Fusarium species infected chilli seeds. American Scientific Research Journal for Engineering, Technology, and Sciences, 29 (1): 182-202.

Johan S, Jesper M. 2005. Antifungal lactic acid bacteria as biopreservatives. Trends Food Science Technology, 1: 7078. DOI:10.1016/j.tifs.2004.02.014

Kim WJ. 1993. Bacteriocins of lactic acid bacteria: their potentials as food preservatives. Food Reviews International, 9: 299-313.

Lutz MP, Michel V, Martinez C, Camps C. 2012. Lactic acid bacteria as biocontrol agents of soil-borne pathogens, IOBCWPRS Bulletin, 78: 285-288, 2012.

Maas JL. 1998. Compendium of Strawberry Diseases. 2 nd ed. St. Paul, MN, USA: APS Press.

Ouwehand A. 1998. In Lactic acid bacteria Microbiology and Functional Aspects. $2^{\text {nd }}$ ed. NY, USA: CRC Press.

Trias R, Baneras L, Montesinos E, Badosa E. 2008. Lactic acid bacteria from fresh fruit and vegetables as biocontrol agents of phytopathogenic bacteria and fungi. Int Microbial., 11: 231-236. DOI: 10.2436/20.1501.01.66.

Turhan G, Turhan K. 1989. Supression of damping off on pepper caused by Phythium ultimum Trow and Rhizoctonia solani Kühn. by Some New Antagonists in Comparison with Trichoderma harzianum Rifai. J Phytopathology., 126: 175182.

Vestberg M, Kukkonen S, Saari K, Parikka P, Huttunen J, Tainio L, Devos N, Weekers F, Kevers C, Thonart P, Lemoine MC, Cordiwe C, Alabouvette C, Gianinazzi S. 2004. Microbial inoculation for improving the growth and health of micropropagated strawberry. Applied Soil Ecology, 27: 243-258. DOI:10.1016/j.apsoil.2004.05.006

Zebboudj N, Yezli W, Hamini-Kadar N, Kihal M, Henni JE. 2014. Antifungal activity of lactic acid bacteria against Fusarium oxysporum f. sp. albedinis isolated from diseased date palm in South Algeria. International Journal of Biosciences, 5 (9): 99-106. 